\title{
An Archaeological Survey for the Southwest Texas Electric Cooperative in Schleicher and Crockett Counties, Texas
}

Michael C. Woerner

Follow this and additional works at: https://scholarworks.sfasu.edu/ita

Part of the American Material Culture Commons, Archaeological Anthropology Commons, Environmental Studies Commons, Other American Studies Commons, Other Arts and Humanities Commons, Other History of Art, Architecture, and Archaeology Commons, and the United States History Commons

Tell us how this article helped you.

This Article is brought to you for free and open access by the Center for Regional Heritage Research at SFA ScholarWorks. It has been accepted for inclusion in Index of Texas Archaeology: Open Access Gray Literature from the Lone Star State by an authorized editor of SFA ScholarWorks. For more information, please contact cdsscholarworks@sfasu.edu. 


\section{An Archaeological Survey for the Southwest Texas Electric Cooperative in Schleicher and Crockett Counties, Texas}

\section{Creative Commons License}

\section{(c) (1) (8)}

This work is licensed under a Creative Commons Attribution-NonCommercial 4.0 International License 


\author{
AN ARCHAEOLOGICAL SURVEY FOR THE \\ SOUTHWEST TEXAS ELECTRIC COOPERATIVE \\ IN SCHLEICHER AND CROCKETT COUNTIES, TEXAS
}

\author{
Michae] C. Woerner
}

Center for Archaeological Research The University of Texas at San Antonio Archaeological Survey Report, No. 109 


\section{ABSTRACT}

In July 1981, the Center for Archaeological Research, The University of Texas at San Antonio, conducted an archaeological survey of power line right-ofways in Schleicher and Crockett Counties. The survey was performed for the Southwest Electric Cooperative, Inc. Eight archaeological sites were located during this project. Three sites (41 SL 5, 41 SL 8, and 41 SL 9) are recommended for additional documentation if they are to be additionaliy disturbed. The other sites found need no further work. 
Page

Abstract ............................. i

Acknowledgments ................... ... $i$...

Introduction ........................... 1

Environmental Background .................. 1

Previous Archaeological Work ................ 4

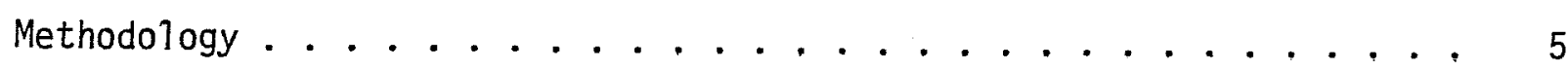

The Survey . . . . . . . . . . . . . . . . . 5

Middle Valley Area. . . . . . . . . . . . . . . 5

Hulldale Area . . . . . . . . . . . . . . 8

Fort Lancaster Area . . . . . . . . . . . . . 12

Summary . . . . . . . . . . . . . . . 12

References Cited ................. 14

\section{LIST OF FIGURES}

Figure

1. Location of Survey Areas in Crockett and Schleicher

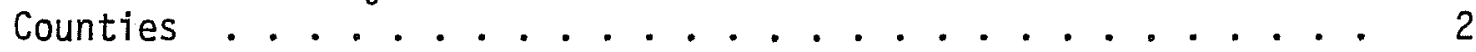

2. Middle Valley Area of Schleicher County . . . . . . . . . 3 3

3. Middle Valley Area of Schleicher County . . . . . . . . . 7

4. Middle Valley Area of Schleicher County . . . . . . . . . 9

5. Hul1dale Area of Schleicher County ............ 10

6. Fort Lancaster Area of Crockett County. . . . . . . . . . 13 


\section{ACKNOWLEDGMENTS}

The author wishes to thank Ron Somerville of Somerville Engineering and Jim Martin of Southwest Texas Electric Cooperative for their courtesies and assistance during the survey.

Thanks are also extended to Jack Eaton, Associate Director, and Thomas R. Hester, Director, the Center for Archaeological Research, for their supervision and advice. 


\section{INTRODUCTION}

In June 1981, Somerville Engineering contracted with the Center for Archaeological Research (CAR), The University of Texas at San Antonio (UTSA), to perform an archaeological survey for the Southwest Texas Electric Cooperative, Inc. in Schleicher and Crockett Counties (Ron Somervi1le, letter dated June 29, 1981).

Field work was conducted during July 6-8 by Michael Woerner, CAR archaeologist, accompanied by Ron Somerville of Somervitle Engineering and Jim Martin of Southwest Texas Electric Cooperative, Inc. Overal1 supervision was administered by Thomas R. Hester and Jack D. Eaton, Director and Associate Director of the Center for Archaeological Research.

The survey covered a total of 28 miles of existing and proposed power 7 ine easements and one substation construction site. Three separate areas were examined (Fig. 1):

Middle Valley Area. A proposed power line easement and new substation site (aTready under construction) were examined. The substation is located approximately 20 miles east of Eldorado, adjacent to the old Sonora-Fort McKavett Road. The proposed power line route extends northeast from the substation and parallel to the road for 3.5 miles. The route then turns due north for 6.5 miles to Hwy. 190, then northeast for 4.5 miles. Four archaeological sites were recorded in this area (Fig. 2).

Hulldale Area. The survey area begins 15 miles north of Eldorado on Hwy. 277 and proceeds east for 12 miles. The right-of-way of a power Tine, constructed one month prior to the survey, was examined for cultural resources. Three archaeological sites and one isolated find were recorded.

Fort Lancaster Area. This area is located 30 miles west of Ozona along Live Oak Creek. The survey area runs through the Live Oak Historical District. Plans are to construct a short section of power line and to upgrade an existing line. One archaeological site was recorded.

\section{ENVIRONMENTAL BACKGROUND}

The Middle Valley and Hulldale survey areas are located in Schleicher County and are on the edge of the Edwards Plateau. These marginal areas. of the Plateau are topographically undulating and deeply dissected with strongly erosional surfaces and slopes (Johnson 1931). Large 1imestone outcrops of Lower Cretaceous age are common throughout the region. The soils have developed from the continuing erosion and weathering of 7 imestone and marls, and are dark colored, finely textured and well aggregated. The deepest soils are found on plateau tops and alluvial floodplains. Soil depth averages 4-10 inches (Anonymous 1958).

The Edwards Plateau is included in the Balconian Biotic Province (Blair 1950). The vegetation of the area is dominated by short grasses, with mesquite and stunted oaks populating the upper slopes and terraces. The climate is semi-arid with hot, dry summers and mild winters. The mean temperature is $66^{\circ}$ and average 


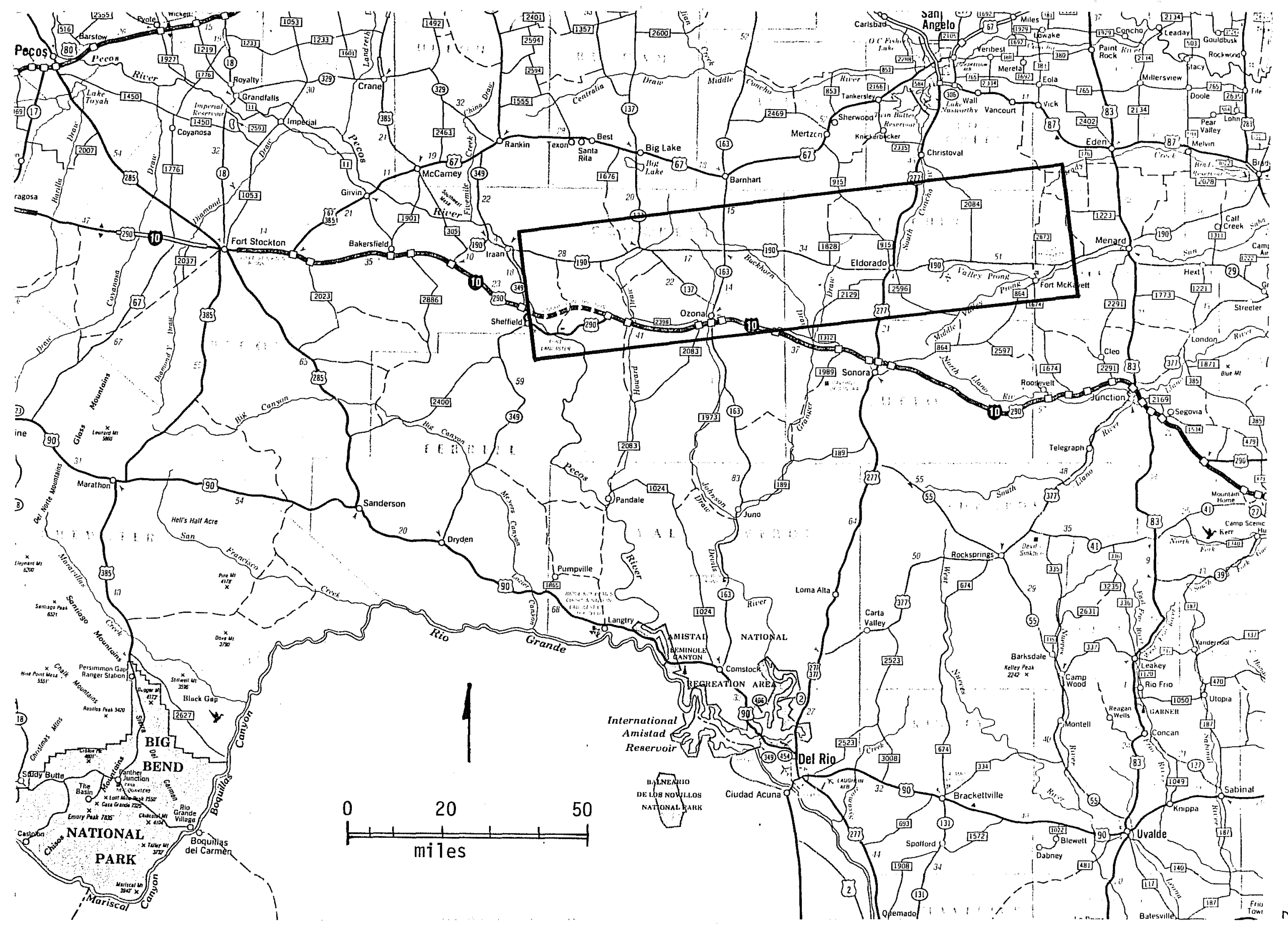

Figure 1. Location of Survey Areas in crockett and Schleicher Counties. 
This page has been

redacted because it

contains restricted

information. 
rainfall is 15 inches. Due to its location, the climatic characteristics of the Edwards Plateau are transitional between the North-Central Plains and the South Texas Plains (Johnson 1931).

The Fort Lancaster survey area is located within the Stockton Plateau, which is the southern extent of the Great Plains Physiographic Province (Fenneman 1931). The chief geological characteristics of the Stockton plateau are the massive horizontal bands of chert bearing 7 imestones formed during the Lower Cretaceous age.

This area is included in the: Chihuahuan Biotic Province (Blair 1950). The vegetation is limited to short grasses, cedar, and stunted oaks. The vegetation and rocky slopes make the area suitable for grazing sheep and goats. The climate is similar to the marginal areas of the Edwards Plateau.

The prehistoric environment was cooler and moister than today. Mammoth and mastodon remains in south Texas indicate grass and parkland elements in the Middle and Late Pleistocene environments (Lundelius 1967:297). Since the end of the Pleistocene, around 8000 B.C., aridity has gradually increased. This change is reflected in pollen and phytolith analysis of south Texas sediments (Bryant 1969; Robinson n.d.). Broad grasslands and abundant surface water were common until the 1800s. The introduction of commercial 7 ivestock, short-term climatic changes, and the suppression of grass fires are factors which have contributed to the recent proliferation of mesquite and scrub brush (Hester 1976, 1980).

Fauna common to both areas include deer, cottontail, jackrabbit, javelina, coyote, wild turkey, dove, and quail.

PREVIOUS ARCHAEOLOGICAL WORK

Schleicher County

Only two sites have been previously recorded in Schleicher County. 41 SL 1 is a possible burial mound recorded in 1929. by R. B. Dickard. The site was reexamined in 1976 by Darrel Creel and may actual1y be 1ocated in Tom Green County.

41 SL 2 is a smal1 ring midden in southeast Schleicher County. The site was recorded by Damon Crawford in 1978 (Luke 1981).

\section{Crockett County}

During the Archaic period (5500 B.C. to A.D. 1000), the western and central portions of Crockett County had strong cultural ties with the Trans-Pecos Region. The lower Pecos-Devils River exercised the strongest influences over the area with lesser influences from the southwest, east, and southeast (Word 1971).

In 1966 Southern Methodist University conducted a survey for the State Building Commission, during which several rockshelters were tested and excavated. 
Also in 1966, the Texas Archeological Society held its summer field school at the Dunlap Site (41 CX 5). A rockshelter and two burned rock middens were excavated (Word 1971).

During 1970-71 the Texas Highway Department conducted a survey along the proposed route of Interstate Highway 10 from Ozona to the Pecos River. Nineteen sites were recorded; the majority were burned rock middens or accumulations, and isolated hearths (Crawford 1971).

Additional work along IH 10 was conducted by the Highway Department in Musk Hog Canyon. An intensive archaeological survey and testing program, in conjunction with the Texas Archeological Society and Texas A\&M University, recorded and inventoried 546 individual features (Luke 1980).

The Fort Lancaster ruins (41 CX 28) in west Crockett County have been assigned to the National Register of Historic Places and 1je within the Live Oak Historic District. The fort was a federal military outpost constructed between 1855-1861 on the old El Paso-San Antonio military road (Anonymous 1976).

\section{METHODOLOGY}

A11 proposed and existing power line and construction sites were carefully examined for cultural resources. In all areas the right-of-way had been cleared of heavy vegetation allowing a thorough examination of the exact route. Particular attention was paid to terraces, slope bases, minor and major drainage embankments, and other areas of high site probability. Areas previousiy impacted by road, site, or power line construction were also examined. When possible, areas of high site probability outside of the easement were also examined. A11 sites were recorded on CAR site survey forms and are on file at the CAR and Texas Archeological Research Laboratory, Austin. Artifacts were collected, proveniences were recorded, and the materials were brought to the CAR for analysis and storage.

THE SURVEY

Middle Valley Area

$41 S L 3$

Location: This site is located along the old Sonora-Fort McKavett Road, $500 \mathrm{~m}$ northeast of the new substation construction (Fig. 2).

Description: The site is a prehistoric open campsite situated on the west slope of a minor drainage. Chert tools and debitage were observed in an area $75 \mathrm{~m}$ east-west by $50 \mathrm{~m}$ north-south.

Artifacts Collected: 6 unifaces, 2 small oval bifaces, 1 large biface fragment, and 1 retouched core. 
Condition: The southern portion of the site has been destroyed by construction of a county road. Additional surface and subsurface disturbance has been caused by land clearing and natural erosion.

Recommendations: Because of severe disturbance, no further archaeological work is recommended.

\section{$41 S L 4$}

Location: This site is located on the proposed power 1 ine route approximately 23 miles east of Eldorado and 7.1 miles north of old Sonora-Fort McKavett Road (Fig. 3).

Description: The site is a small campsite and quarry area on a slope above a minor drainage. A light surface scatter of chert debitage roughly $80 \mathrm{~m}$ in diameter was observed.

Artifacts Collected: No collection was made; however, scattered flakes, tested cobbles, and cores were observed.

Condition: The site area has little soil or vegetation (other than scattered short grasses) to prevent erosion of cultural material. Easement clearance and fenceline construction have caused minor damage to site.

Recommendations: No further archaeological work is recommended for this site.

\section{$41 S L 5$}

Location: The site is located on the proposed power i ine route approximately 23 miles east of Eldorado and 2.9 miles north of old Sonora-Fort McKavett Road (Fig. 3).

Description: This is a moderately dense quarry site situated in and along a minor drainage channel. The site is roughiy rectangular in shape, extending 90-100 m east-west (parallel to drainage) and $40 \mathrm{~m}$ north-south. Since no diagnostic tool forms were observed, the age and cultural affiliations of the site are uncertain.

Artifacts Collected: 2 unifaces, 2 oval bifaces, 1 crude core, and 2 trimmed flakes. In addition to the material collected, chert flakes, cores, and tested cobbles were observed throughout the site area.

Condition: The site is in good condition and disturbed only by natural erosion and by clearing of vegetation along the proposed easement. Because of shallow soil depth and light vegetation, further erosion is the greatest danger to the site at this time.

Recommendations: Should the site be threatened by surface or subsurface disturbance, other than post-hole digging for power line, further work is needed. In this event, we recommend detailed site mapping, controlled surface collection, and if feasible, subsurface archaeological testing. 
This page has been

redacted because it

contains restricted

information. 


\section{$41 S L 6$}

Location: The site is located along a proposed power 1 ine route 22 miles east of Eldorado and 0.8 miles northeast of Hwy. 190 (Fig. 4).

Description: This site is a sma11, Tight density quarry located on a slope above East Poor Hollow. A thin scatter of chert flakes and tested cobbles were observed in an area $50 \mathrm{~m}$ in diameter.

Artifacts Collected: No collection was made. The majority of chert present consisted of patinated, naturaliy modified chert cobbles. One core, some scattered flakes, and tested cobbles were observed.

Condition: The site has suffered minor subsurface disturbance from clearing the easement of vegetation. Otherwise, it is in good condition and relatively undisturbed except for natural erosion.

Recommendations: No further archaeological work is recommended.

Hulldale Area

41 SL 7

Location: The site is located along a recently constructed power 7 ine 15 miles north of Eldorado and 1.6 miles west of US 277 (Fig. 5).

Description: The site is a small, light density quarry on a slope above a minor drainage. A scatter of chert debitage was observed in an area $90 \mathrm{~m}$ east-west by $50 \mathrm{~m}$ north-south. Since diagnostic tool forms are absent, the age and cultural affiliations of the site are uncertain.

Artifacts Collected: Chert debitage, including flakes, cores and tested cobbles, was observed. No collection was made.

Condition: Site condition is good despite recent construction of a power line through its southern edge. Site has been subjected to minor natural erosion.

Recommendations: No further archaeological work is recommended.

$41 S L 8$

Location: The site is located along a newly constructed power 1 ine 15 miles north of Eldorado and 3.8 miles east of Hwy. 277 (Fig. 5).

Description: The site is a large, moderately dense quarry on minor tributary feeding into Bois D'Arc Draw. Quarry material is exposed on surface bedrock of a gentle slope above drainage.

Artifacts collected: 1 small biface, 3 cores, 4 retouched flakes, 3 secondary flakes, and 6 interior flakes. 
This page has been

redacted because it

contains restricted

information. 
This page has been

redacted because it

contains restricted

information. 
The chert is dark brown to gray, often with bands of white or light gray. The flakes collected are crude, thick specimens with large platforms (up to $3 \mathrm{~cm}$ in length) and prominent bulbs. Few small thinning flakes were observed.

Condition: Site has been partially disrupted by the construction of the power Tine and a fenceline. There is little soil or vegetation to prevent natural erosion. General site condition is good.

Recommendations: Should the site be threatened with additional surface or subsurface disruption, further work is recommended. This would include detailed site mapping, controlled surface collection, and subsurface archaeological testing if deemed feasible.

\section{$41 S L 9$}

Location: The site is located along the recently constructed power line 15 miles north of Eldorado and 4.5 miles west of US 277 (Fig. 5).

Description: The site is a large, dense quarry on the west bank of a minor tributary of Bois D'Arc Draw. The surface is littered with chert debitage. It is roughly oval in shape with a long axis $90 \mathrm{~m}$ east-west and a short axis $50 \mathrm{~m}$ north-south.

Artifiacts collected: 1 smal1 biface, 3 unifaces, 5 secondary flakes, 7 interior flakes, 3 cores, and 4 chert chunks.

The chert is consistently dark gray or blue with bands of white or gray. Most of the debitage observed consisted of large secondary and interior flakes. The flakes are generally thick with large striking platforms (up to $20 \mathrm{~mm}$ in length) and prominent bulbs. Few small fine thinning flakes were observed.

Condition: Although the site has been partially disrupted by the construction of the power line and a fenceline, its condition is good. There is little soil soil or vegetation to prevent natural erosion.

Recommendations: Should the site be threatened with additional surface or subsurface disruption, further work is recommended. This would include detailed site mapping, controlled surface collection, and subsurface archaeological testing if deemed feasible.

\section{ISOLATED FIND}

A fragmented Langtry point, missing the distal tip and both barbs, was recovered from a sendero approximately $700-800 \mathrm{~m}$ east of $41 \mathrm{SL}$ 8. It is made of a medium brown, light7y banded chert and is Middle Archaic in date (Hester 1980). Because the point is a fragmented surface find and is unassociated with other archaeological provenience, no further investigation is needed. 
Fort Lancaster Area

\section{CX 756}

Location: The site is located 30 miles west of Ozona, between Hwy. 290 and IH 10, on the Live Oak Creek drainage. The site is just within the boundaries of the Live Oak Historic District (Fig. 6).

Description: The site is a small, open, light density campsite on the east bank of Live Oak Creek. Burned rock, chert debitage, and a point fragment were observed. Despite large quantities of burned rock, no discrete concentrations were observed. The burned rock may be a result of recent land disturbance activities. The site is elongated in shape with a major axis $50 \mathrm{~m}$ in length, parallel to the drainage, and the minor axis $25 \mathrm{~m}$ in width. The Pedernales point collected here suggests a Middle Archaic (2000 B.C.-A.D. 1000) occupation.

Artifacts callected: 1 Pedernales point fragment. The point is missing the distal portion of the blade and has slightly convex lateral edges with pronounced shoulders. The stem is rectangular with a notched base. The point is made from a light gray, coarse-grained chert, lightly patinated, and is Middle Archaic in date (Hester 1980).

Condition: The site has been badiy disturbed by construction of a subsurface oit pipeTine and an above ground power line through the middle of the site. The area is also subjected to minor erosion and periodic flooding of Live Oak Creek.

Recommendations: The site has been too badly damaged to warrant further archaeologicat work.

\section{SUMMARY}

The current project was a three-day archaeological survey in Schleicher and Crockett Counties where the Southwest Texas Electric Cooperative will be extending service to new areas and upgrading existing power 1ines. Three separate areas, totaling 28 miles of proposed and existing power line easements and a substation construction site, were examined for cultural resources.

In the Middle Valley survey area of Schleicher County, four archaeological sites were recorded ( $41 \mathrm{SL} 3,41 \mathrm{SL} 4,41 \mathrm{SL} \mathrm{5}$, and $47 \mathrm{SL} 6$ ). Of these, only 41 SL 5 would need additional study should the site be threatened by planned disturbance. The other sites require no further work.

The Hulldale area survey of Schleicher County recorded three archaeological sites (41 SL 7, $41 \mathrm{SL} 8$, and $47 \mathrm{SL} 9$ ). Additional archaeological study would be needed at 41 SL 8 and 41 SL 9 only if the sites are to be threatened by p. Tanned disturbance.

One archaeological site ( 41 CX 756) was recorded in the Fort Lancaster survey area of Crockett County. However, because of severe disturbance at the site, no further work is needed. 
This page has been

redacted because it

contains restricted

information. 


\section{REFERENCES CITED}

Anonymous

1958 Watershed Work Plan for Watershed Protection and Flood Prevention of Dry Devil's River and Lowry Draw Watershed, Sutton and Schleicher Counties, Texas. Prepared under the authority of the United States Department of Agriculture and the Soif Conservation Service.

Anonymous

1976 The National Register of Historic Places in Texas. Texas Historical Commission, Austin.

Blair, W. F.

1950 The Biotic Provinces of Texas. Texas Journal of Science 2(1): 93-117.

Bryant, V. M.

1969 Late Full-Glacial and Post Glacial Analysis of-Texas Sediments. Ph.D. dissertation, The University of Texas at Austin.

Crawford, D. D.

1971 An Archaeological Survey on Interstate Highway 10. Texas Highway Department Publications in Archaeology Report 2. Austin.

Fenneman, N. M.

1931 Physiography of the Western united States. McGraw-Hi11, New York. Hester, T. R.

1976 Hunters and Gatherers of the Rio Grande Plain and the Lower Coast of Texas. Center for Archaeological Research, The University of Texas at San Antonio.

1980 Digging into South Texas Prehistory. Corona Publishing Company, San Antonio.

Johnson, E. H.

1931 Natural Regions of Texas. The University of Texas Bulletin 3113. Luke, C. J.

1980 Test Excavations at the Famous Amos Site, Crockett County, Texas. Texas Highway Department Publications in Archaeology Report 17. Austin. 
1981 Test Excavations at Three Burned Rock Midden Sites in Sutton and Schleicher Counties, Texas. Texas Department of Highways Publications in Archaeology Report 19. Austin.

Lundelius, E. L., Jr.

1967 Late-Pleistocene and Holocene Faunal History of Central Texas. In P. Martin and H. Wright, Jr., Eds., Pleistocene Extinctions: 287-320. New Haven.

Robinson, R. L.

n.d. The Study of Biosilica: Reconstructing the Paleoenvironment of the Central Coastal Plain of Texas. Center for Archaeological Research, The University of Texas at San Antonio. In preparation.

Word, J. J.

1971 The Dun1ap Complex in Western-Central Crockett County. Bulletin of the Texas Archeological Society 42:271-318. 